九州大学学術情報リポジトリ

Kyushu University Institutional Repository

\title{
Descriptions of the Egg and First-Instar Larva of Clytra arida Weise (Coleoptera : Chrysomelidae)
}

Lee, Jong Eun

Entomological Laboratory, Faculty of Agriculture, Kyushu University

Morimoto, Katsura

Entomological Laboratory, Faculty of Agriculture, Kyushu University

https://doi.org/10.5109/23954

出版情報: 九州大学大学院農学研究院紀要. 35 (3/4)，pp.93-99，1991-02. Kyushu University バージョン：

権利関係 : 


\title{
Descriptions of the Egg and First-Instar Larva of Clytra arida Weise (Coleoptera : Chrysomelidae)*
}

\author{
Jong $E$ un Lee and K atsura M orimoto \\ Entomological Laboratory, Faculty of Agriculture, \\ Kyushu University, Fukuoka 812, Japan
}

(Received September 25,1990)

\begin{abstract}
The egg and first-instar larva of Clytra arida Weise are described and illustrated for the first time from Japan, and the affinity of the subfamily Clytrinae to the Cryptocephalinae and Chlamisinae is reconfirmed on the larval characters.
\end{abstract}

\section{INTRODUCTION}

The genus Clytra is an extremely small genus of the subfamily Clytrinae distributed in America, Europe and Asia, and only one species, Clytra arida Weise, is reported to occur in Japan.

The larvae of this genus are known to live in the nests of the ant genera Formica, Camponotus, Lasius and Cataglyphis (Medvedev, 1962). According to the study on European Clytraquadripunctata by Donisthorpe (1902), the female drops the eggs on to the ground beneath from a tree or shrub above or close to a nest of host ant. The egg is held in the depression of the abdomen and an excrement is coated by rotating it by the hind tarsi before dropping. The covered egg looks like a small plant detritus, and is carried by the ant into the nest. The larva lives in the nest of ant in a case, and feeds on vegetable refuse there. Biology of the Japanese species is not known except for its host plants of the adult.

For the larvae of this genus, Clytraquadripunctata was first properly illustrated by Böving and Craighead (1931). Descriptions and a key to genera and species of the Clytrinae by the larvae were presented by Medvedev (1962) including Clytraquadripunctata and C. atraphaxidis, and another key was made by Gulyarov and Medvedev (1964) by adding C. laeviuscula to these two species. The present paper is aimed to provide detailed descriptions of the egg and the first-instar larva of Clytra arida as the basic data for the phylogenetic study of the family Chrysomelidae.

\section{MATERIALS AND METHODS}

The material used in this study was obtained by rearing the adults in the laboratory. The eggs and larvae were preserved in $70 \%$ ethyl alcohol. The larva was macerated in $10 \% \mathrm{KOH}$ solution for several minutes. The dissection was carried out under a stereoscopic microscope, using a sharp needle and pointed forceps. For

\footnotetext{
*Contribution from the Entomological Laboratory, Faculty of Agriculture, Kyushu University, Fukuoka (Ser. 4, No. 18).
} 
detailed morphological studies on the minute structure of the larva, the parts were mounted on slides and observed through the compound microscope. The morphological terms used in this study are followed principally after LeSage (1982).

\section{IMMATURE STAGES}

\section{Clytra arida Weise}

(Figs. 1-3)

Egg. Egg covered by a case like a small pinecone (Fig. 1. C), brown, 1.4-1.8 mm long, 1.1-1.2 mm wide $(\mathrm{n}=10)$; egg stalk absent.

Larva. Body typically J-shaped, with last five abdominal segments directed forwards (Fig. 1. A). Head brown, prothorax pale brown, meso-and metathorax and abdomen yellowish ; legs pale brown, long and slender. Egg bursters present on DLpi of meso-and metathorax.

Head (Fig. 2. A, C). Hypognathous, oval, well sclerotized. Epicranial suture well developed, Y-shaped ; coronal suture about one-third the length of head, frontal sutures broadly divergent and weakly bisinuate. Stemmata (Fig. 2. C) well developed, 6 in number, distributed in 2 groups, 4 pairs of posterior stemmata behind antennae and 2 pairs of anterior stemmata below antennal bases ; 3 pairs of stemmatal setae (ss) present, ssl below posterior group of stemmata, $\mathrm{ss}^{2}-3$ in anterior group of stemmata. Epicranium (Fig. 2. A, C) with 4 pairs of posterior minute epicranial setae (pesl-4) arranged in oblique row beside posterior epicranial sensillum (pesm) ; 5 pairs of dorsal epicranial setae (des); desl papillate, des2 and 3 simple, des 4 and 5 filiform and weakly papillate ; desl before desml, des 2 more lateral in position, des 3 long, des 4 short and between desm 2 and desm3, des 5 rather long and above posterior stemmata; 3 pairs of lateral epicranial setae (les) ; lesl simple between lesml and lesm2, les2 simple and beside posterior stemmata, les 3 simple and beside lesm2 ; ventral epicranial sensilla (vesm) below desml. Frons (Fig. 2. A, C) with 6 pairs of papillate frontal setae (fs) arranged in 3 transverse rows : fsl located in basal fifth above frontal sensilla fsm forming first row ; fs2 and fs 3 corresponding to second row ; fs4-6 filiform and weakly papillate in line at apex of frons, making third row. Frons, clypeus and labrum completely fused, without their boundaris. One pair of filiform and weakly papillate clypeal setae (csl) and 1 pair of sensilla (csm) located medially in fusion area of frons and clypeus. Three pairs of labral setae (lbs) present ; lbs1 simple, on disc below csl, lbs2 filiform and weakly papillate, along lateral margins, lbs3 papillate, along lateral margins. Labrum (Fig. 1. F and Fig. 2. A) transverse ; anterior margin sinuate with 3 weak protrusions, median part of anterior margin double edged dorso-ventrally, its ventral edge produced semicircularly. Epipharynx (Fig. 1. B, F) with 7 pairs of anterior epipharyngeal spiniform setae (esl-7) , of which outermost one short ; epipharyngeal sensilla (epsm) grouped in 2 clusters : 2 in anterior cluster, 10 in posterior cluster on U-shaped line. Antenna (Fig. 2. B) 2-segmented, segment 1 with 2 sensilla, segment 2 with a membranous dome-like sensory papilla and 8 minute and one long seta at apex. Mandible (Fig. 1. E) with 4 teeth, without mola, penicillus and retinaculum, with 2 mandibular setae $(\mathrm{ms})$ and 1 sensillum $(\mathrm{msml})$ located dorsoventrally, and 1 sensillum $(\mathrm{msm} 2)$ near base of innermost tooth. Labium (Fig. 3. B, C) with prementum and postmentum not fused together ; postmentum with 3 pairs of postmental setae (pos1- 


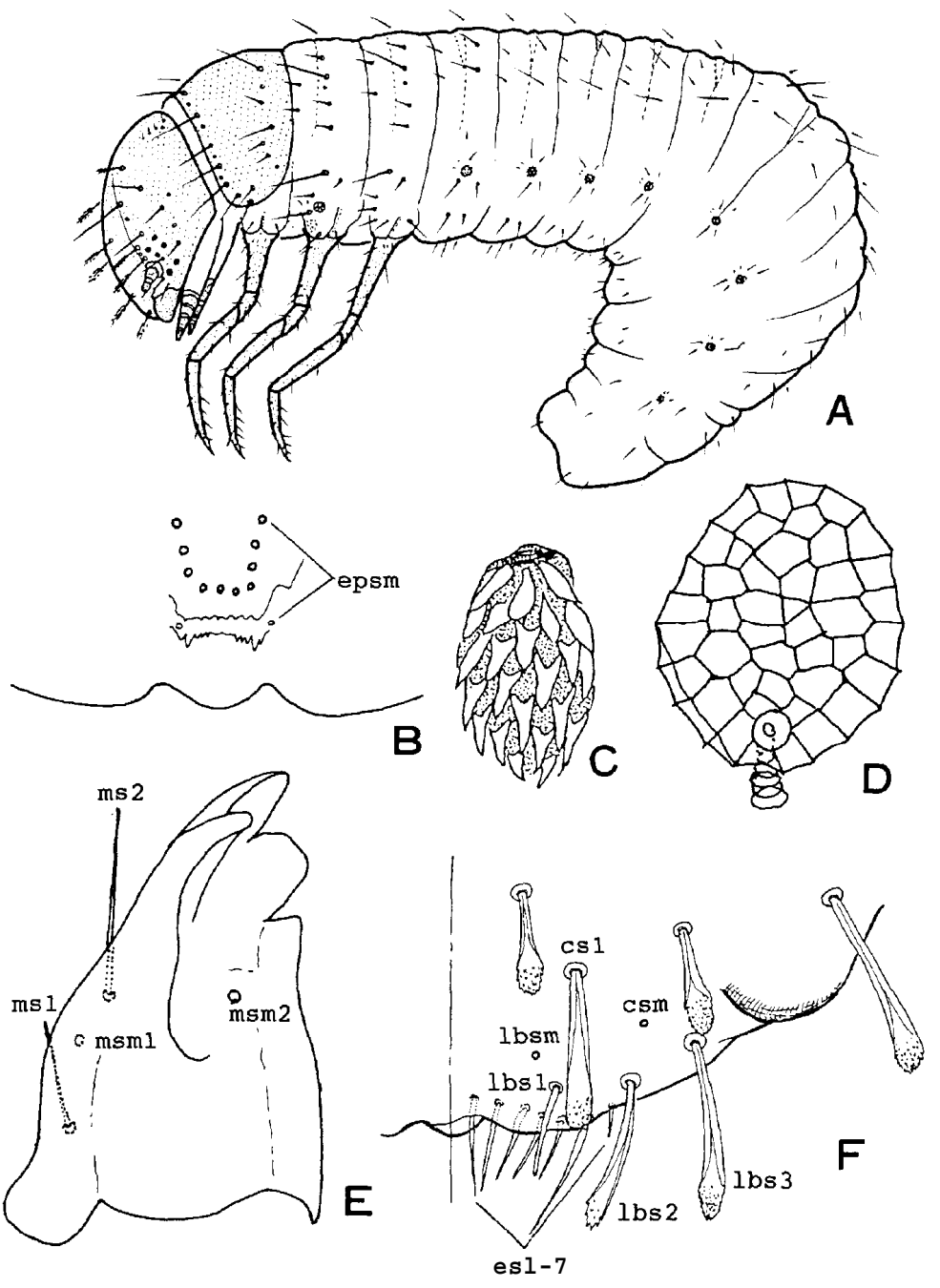

Fig. 1. Clytra arida Weise. A, larva, case removed, lateral view ; B, epipharynx ; $\mathrm{C}$, egg ; D, 1st abdominal spiracle ; E, mandible, ventral view ; F, clypeus, labrum and epipharynx, dorsal view. 


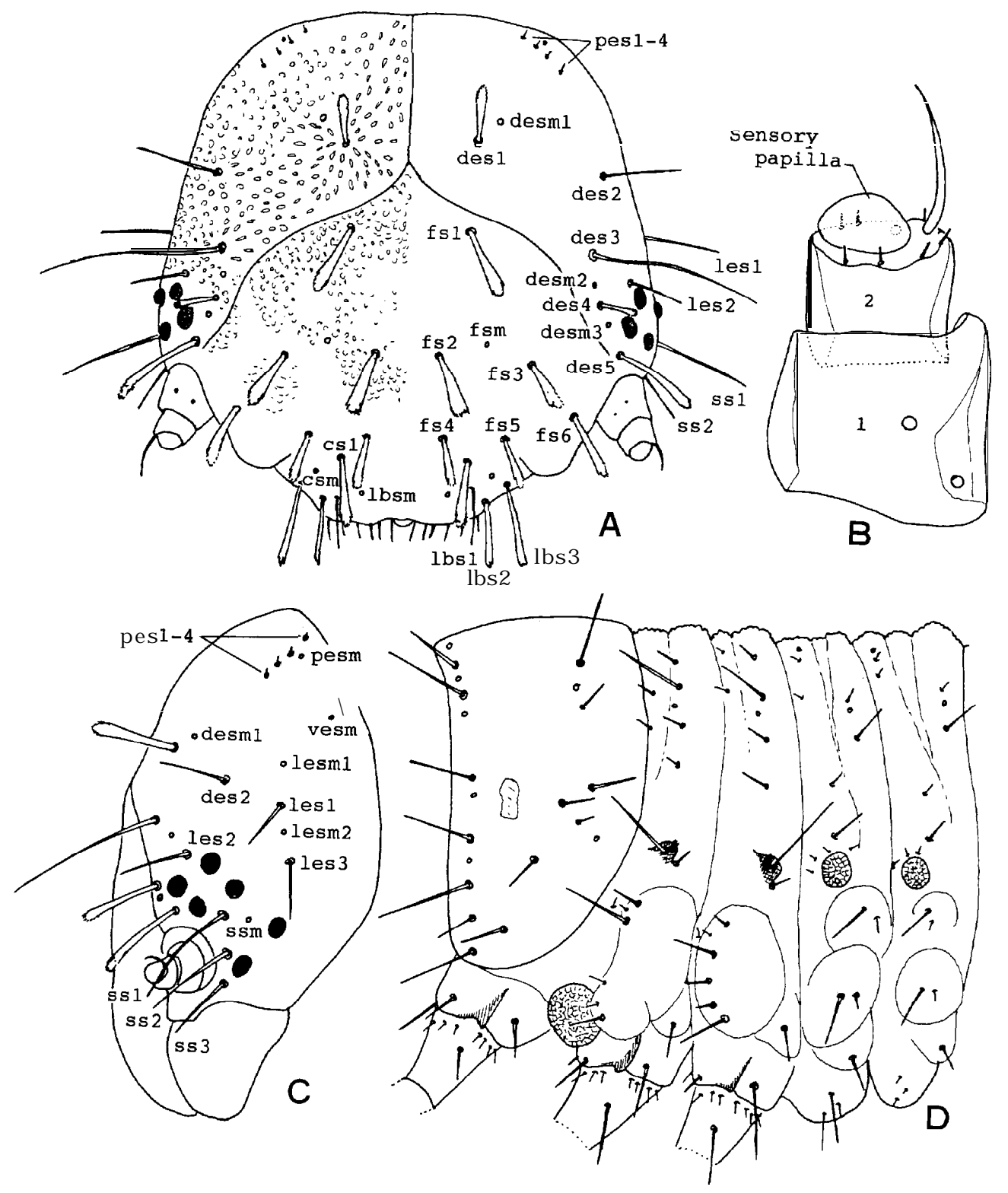

Fig. 2. Clytra arida Weise, larva. A, head, dorsal view ; B, antenna ; C, head, lateral view; $\mathrm{D}$, thorax and abdominal segments 1 and 2 , lateral view. 


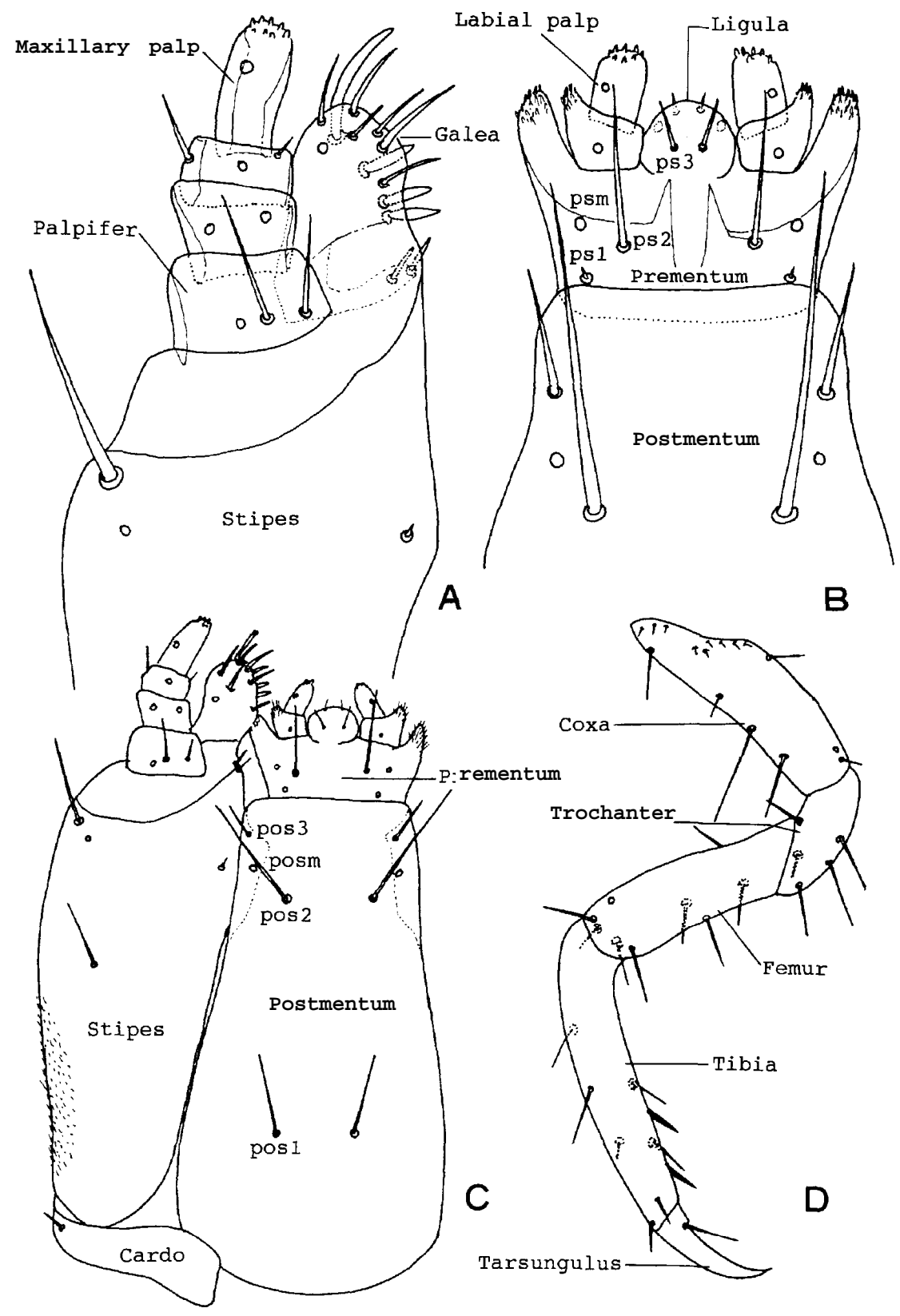

Fig. 3. Clytraarida Weise, larva. A, maxilla ; B and C, labium, ventral view ; D, fore leg, lateral view. 
3) and 1 pair of sensilla (posm) ; prementum with 3 pairs of premental setae (ps1-3) and 1 pair of sensilla (psm), with numerous microtricha on protrudent parts ; ligula with 1 pair of setae and 1 pair of sensilla. Labial palp 2-segmented, segment 1 with 1 sensillum and numerous microtrichia externally, segment 2 with 1 sensillum. Maxillary palp 3-segmented, segment 1 with 2 sensilla, segment 2 with 2 setae and 1 sensillum, segment 3 with 1 sensillum. Palpifer with 2 setae and 1 sensillum. Stipes with 2 rather large outer marginal setae, 1 minute inner seta, 1 sensillum and numerous microtrichia on latero-posterior surface ; lacinia fused with stipes, forming elongate process at inner apical corner of stipes, bearing 2 spiniform apical setae ;galea with 6 ventral and 4 dorsal setae and 1 ventral sensillum. Cardo with 1 seta.

Thorax (Fig. 2. D). Pronotum well sclerotized, pale brown, with 14 pairs of setae and 7 pairs of sensilla. Meso- and metanotum yellowish, not sclertized, bearing a few setae. Mesothoracic spiracle (Fig. 1. A, D) uniforous, situated on epipleural anterior (EPa) part ; peritreme oval, convex, reticulate ; spiracular opening round. Legs (Fig. 3. D) elongate, without pulvillus. Pro-, meso-, and metathoracic legs similar in color, shape and chaetotaxy ; coxa with 15 setae (9 of them minute), trochanter with 5 setae, femur with 8 setae and 1 sensillum, tibia with 9 setae ( 2 of them stout and spiniform); tarsungulus slightly curved, falciform, with 1 seta at base.

Abdomen. Strongly bent forwards (Fig. 1. A), J-shaped, not sclerotized. Spiracles present on segments 1-8 similar to mesothoracic spiracles but smaller. Epipleuron and pleuron each with 2 setae on each side ; pedal area with 1 seta on each side ; eusternum with 3 setae on each side.

Larval case. Shape pinecone-like, 1.8-2.0 mm long, 1.2-1.3 $\mathrm{mm}$ at widest diameter $(\mathrm{n}=10)$. Color dark brown. The larval case is essentially similar in shape and color to eggs.

Body length: $1.8 \mathrm{~mm}$.

Head width : $0.53 \mathrm{~mm}$.

Material examined. Togakushi, Nagano Pref., 17. VII. 1988, larvae collected and reared on leaves of Lespedeza cyrtobotrya Miq.

\section{DISCUSSION}

The larva of this species is separable from the other known species by the surface sculpture of the head, and number and arrangement of the papillate setae on the epicranium. Though Böving and Craighead (1931) figured only five stemmata (= ocelli) on the larva of Clytraquadripunctata, they probably overloocked one stemma in the ventral group, which has always two stemmata in Japanese species. These stemmata are black and shiny like the head capsule itself, and consequently difficult to see.

The larvae of the subfamily Clytrinae show many affinities with those of the Cryptocephalinae and Chlamisinae on the following points : The abdomen bends J-shapedly, with the last five abdominal segments directing forwards for an adaptation of the life in a case. The frons and clypeus are fused and their boundary suture is absent. The endocarina is absent. The maxillary palp is three-segmented excluding palpifer. The lacinia is fused with the stipes. The egg-bursters are present on the dorso-lateral postero-interior (DLpi) part of the meso-and metathorax. But this subfamily is characteristic in the antenna, which is two-segmented, and its sensory 
papilla is a broad and pillbox-shaped. The chaetotaxy of the head, thorax and abdomen has not been properly described nor compared on the larvae of these subfamilies. The spiracle of Clytraarida is remarkable by the convex and reticulate peritreme.

\section{REFERENCES}

Böving, A. G. and F. C. Craighead 1931 An illustrated synopsis of the principal larval forms of the order Coleoptera. Ent. Amer., 11: 1-351

Donisthorpe, H. 1902 The life history of Clytra quadripunctata L., Trans. Ent. Soc. Lond., 11-23

Gulyarov, M. S. and L. N. Medvedev. 1964 Key for the identification of the genera of the subfamily Clytrinae. In Arnoldi, L. B. et al. eds. Key to soil dwelling insect larvae. 919 pp. USSR Acad. Sci. Press, Moscow. 519-521 (In Russian)

LeSage, L. 1982 The immature stages of Exema canadensis Fierce (Coleoptera, Chrysomelidae). Coleopt. Bull., $36: 318-327$

Medvedev, L. N. 1962 Systematics and biology of the subfamily Clytrinae (Coleoptera, Chrysomelidae). Zool.Zh., 41 (9):1334-1344 (In Russian) 